\title{
Numerical evaluation of passive strategies for nocturnal climate optimization in a greenhouse designed for rose production (Rosa spp.)
}

\author{
Edwin Andres Villagran Munar', Carlos Ricardo Bojaca Aldana²
}

\begin{abstract}
In passive plastic greenhouses that do not have heating systems, the phenomenon of thermal inversion occurs, which means that the temperature inside the greenhouse is lower than the outdoor environment; therefore, the plants are exposed to thermal conditions that are unsuitable for production. The aim of this work was to evaluate passive air climatization alternatives seeking to optimize the nocturnal microclimate of a multi-tunnel Gothic greenhouse projected for rose production in Bogota savannah. The experimental approach included the use of a CFD-2D simulation model successfully validated by recording and archive of temperature data in a greenhouse. A total of 24 steady-state simulations were developed that included 3 nighttime temperature values, 2 sky conditions and 4 greenhouse configurations. The results showed that under the clear sky condition there was a thermal inversion with a value of -0.53 and $-1.11{ }^{\circ} \mathrm{C}$ for the standard night-time greenhouse configuration. The installation of a thermal screen and porous mesh in the fixed roof vents allowed to control the presence of thermal inversion under clear sky conditions and optimizing the indoor temperature value in the greenhouse under cloudy sky conditions.
\end{abstract}

Keywords: CFD simulation, Thermal inversion, Temperature, airflow pattern.

Resumo

Avaliação numérica de estratégias passivas para a otimização climática noturna de uma estufa projetada para a produção de rosas. (Rosa spp.)

Nas estufas de plástico passivo que não possuem sistemas de aquecimento, ocorre o fenómeno da inversão térmica, o que significa que a temperatura no interior da estufa é inferior à do ambiente exterior, pelo que as plantas estão expostas a condições térmicas impróprias para a produção. O objetivo deste trabalho foi avaliar alternativas de ar condicionado passivo visando otimizar o microclima noturno de uma estufa gótica multi-túnel proposta para a produção de rosas na savana de Bogotá. A abordagem experimental incluiu o uso de um modelo de simulação CFD-2D validado com sucesso através da captura e coleta de dados de temperatura na estufa real. Um total de 24 simulações em estado estacionário foram desenvolvidas, incluindo 3 valores de temperatura noturna, 2 condições de céu e 4 configurações de estufa, os resultados obtidos mostraram que sob a condição de céu limpo houve uma inversão térmica com um valor de $-0,53$ e $-1,11{ }^{\circ} \mathrm{C}$ para a configuração noturna padrão da estufa, também se verificou que a instalação de uma tela térmica e uma malha porosa na ventilação fixa do telhado permitiu limitar a presença de inversão térmica sob condições de céu limpo e otimizou o valor da temperatura interna no inversor sob condições de céu nublado. Palavras-chave: Simulação CFD, Inversão térmica, Temperatura, Padrão de fluxo de ar.

\section{Introduction}

In Colombia since the appearance of the ornamental and the cut flowers sectors at the end of the 1950's, the use of passive polyethylene greenhouses has been supported. This type of structure is considered of low technological level and therefore of easy construction and operating cost, mainly due to the nonexistence of active climate control equipments, and is widely used alternative in tropical and subtropical countries with favorable climates for agricultural production (McCartney et al., 2018). Colombian greenhouses have experienced a series of structural evolutions conceived from the traditional model, which has allowed greenhouses of greater size and robustness and with greater time durability, although the microclimate behavior of this group of greenhouses is very questioned, once extreme levels of humidity and temperature are generated, affecting the yield in some

\footnotetext{
${ }^{1}$ Universidad Jorge Tadeo Lozano, Facultad de Ciencias Naturales e Ingeniería, Departamento de Ciencias Biológicas y Ambientales, Bogotá, Colombia. *Corresponding autor: edwina.villagranm@utadeo.edu.co.

${ }^{2}$ Universidad Jorge Tadeo Lozano, Facultad de Ciencias Naturales e Ingeniería, Departamento de Ciencias Básicas y Modelado, Bogotá, Colombia.
} 
species of high commercial interest in the international markets, mainly rose (Villagran and Bojaca, 2019a). Rose is a plant belonging to the Rosacea family that has more than 30 thousand varieties derived from crosses or backcrossing and is considered one of the most important ornamental plants in the world (Dotto et al., 2016; Reis et al., 2016). Currently, Colombia is the second largest exporter of flowers in the world after the Netherlands and the first in the Americas contributing an approximate share of $15 \%$ to the total world market for cut flowers. According to reports given by the Chain of Flowers and Foliage of the Ministry of Agriculture and Rural Development (MADR) for 2017 registered 8,004 ha dedicated to the production of ornamentals, an area that are distributed in the departments of Cundinamarca and Antioquia. The estimated total annual production of stems is 242,944 tons. This productive sector provides a relevant economic income in the national agricultural sector, generating a foreign exchange income close to 1400 million dollars a year, where the rose provides US\$ 6.9 by $\mathrm{kg}$ exported and occupies a volume of $30 \%$ of the total stems exported in Colombia.

The generation of microclimate inside passive greenhouses is directly related to the external climatic conditions, area and volume of a greenhouse, magnitude and efficiency of the ventilation rates produced in each type of structure (Espinoza et al., 2017). It is known that Colombian greenhouses are deficient in this aerodynamic aspect, with low ventilation rates and inadequate airflow circulation, factors that have been studied and improved through new greenhouse designed for the predominant climatic conditions of the Bogotá savannah (Villagran and Bojaca, 2019b, 2019a). These applications include an increase of ventilation surfaces in the greenhouse roof zone and an average increase of $1.5 \mathrm{~m}$ in the overall height of the greenhouse, generating significant increases in ventilation rates obtaining values higher than the minimum recommended value of $0.04 \mathrm{~m}^{3} \mathrm{~m}^{2} \mathrm{~s}^{-1}$, propitiating a homogeneous temperature with thermal differentials between the exterior and interior environment lower than $2{ }^{\circ} \mathrm{C}$, results that coincide with works developed for other types of passive greenhouses located in other latitudes (Baeza et al., 2009; He et al., 2015).

Passive greenhouses that lack heating systems have their only method of climate control at night, the total closure of the ventilation openings side and front with a sheet of polyethylene, which pursues that the energy captured in the soil of the greenhouse during the day maintain the temperature in the cultivation area at night period in the highest possible value. In this way, it is required to prevent or limit thermal inversion in the indoor environment, a phenomenon in which the temperature of the greenhouse is lower than the surrounding outside air, this phenomenon occurs more frequently under clear sky conditions at night and is produced by far infrared emission from the greenhouse floor (Montero et al., 2016). The phenomenon is characteristic of some passive greenhouses, mainly those with polyethylene cover (Villagran and Bojaca, 2019c; Villagran et al., 2018). One of the causes for thermal inversion is precisely the limited capacity of greenhouses to store heat captured during the day, as it is lost in a very accelerated process during the first hours of night, especially through the roof area and roof apertures that do not have automatic or manual closing systems (Majdoubi et al., 2017). These low temperatures limit the potential production of the crop because of the reduction of its development and in a more critical situations may cause the irreversible crop losses when extreme phenomena such as frost occur; therefore, it is a current need to develop economic and technically viable strategies to optimize the nighttime climate in greenhouses used for the production of ornamentals under Colombian climatic conditions.

One of the most interesting and widely applied modeling and simulation techniques for aerodynamic and microclimate studies in greenhouses has been computational fluid dynamics (CFD) which is currently known as a robust, mature and advanced technique for design in many engineering fields (Dhiman et al., 2019). CFD models have the main advantage of offering fast solutions to evaluate in real or imaginary scenarios that include structural modifications, shape, type and roofing material, allowing to evaluate their efficiency without the requirement to be built on a real scale; thus, becoming a useful tool for the optimization of microclimate generated in greenhouses (Mesmoudi et al., 2017). The works dedicated to the study of the nocturnal microclimate in passive greenhouses by this methodology are scarce compared with those developed for diurnal conditions, the description of the scalar fields of variables as temperature and of air flow of nocturnal climatic conditions patterns can be developed by a model of radiation of discrete order (DO), which allows to simulate numerically the flow of energy that occurs by radiation from the floor of the greenhouse to the external environment (Fidaros et al., 2010).

The use of the simulation model made possible to compare the different passive energy saving strategies, showing the positive effect of increasing the air temperature through the use of double plastic roof coverings. in northern Patagonia under three atmospheric conditions and two types of roofing (Montero et al., 2005). Montero et al. (2013) carried out a 2D simulation study of a passive greenhouse reported that in clear and dry nights the phenomenon of thermal inversion was presented in the simulation scenario of standard configuration of the greenhouse, additionally this work generated the necessary bases to carry out the study of the nocturnal climate of greenhouses equipped with heating. Espinal-Montes et al. (2015) developed a 3D model to evaluate the nocturnal thermal behavior of a Mexican greenhouse, finding that the thermal behavior of the greenhouse with closed windows showed an average thermal inversion of $-3.1{ }^{\circ} \mathrm{C}$ and with open windows the CFD model predicted a thermal inversion of $-0.8{ }^{\circ} \mathrm{C}$. Other works related to this nocturnal weather condition (Majdoubi et al. 2017, 2016) analyzed nighttime heat loss as a function of the radiative and convective energy losses of the roof and the effect of the use of a thermal cover.

This paper proposes the use a numerical simulation model CFD-2D, experimentally validated, with the objective of simulate and evaluate the nocturnal thermal 
comportment generated by three passive air conditioning strategies, (i) use of a porous mesh installed in the fixed roof ventilations, (ii) use of a thermal screen extended over the upper part of the crop and (iii) a combination of the two previous ones, in a non-heated passive greenhouse of multi-tunnel Gothic type located in the savannah at Bogota projected for rose production.

\section{Materials and methods}

Experimental greenhouse and nocturnal climatic conditions

The experimental greenhouse used in this study is a commercial model designed to produce cut rose and built in the savannah of Bogotá, Colombia $\left(4^{\circ} 40.5^{\prime} \mathrm{N}, 74^{\circ} 12.5^{\prime} \mathrm{W}\right.$ and an altitude of 2560 m.a.s.l.). The greenhouse is of the multi-tunnel Gothic type (Figure 1A) covered with transparent polyethylene plastic $(200 \mu \mathrm{m}$ thick), with a total covered area of $4,704 \mathrm{~m}^{2}$, equivalent to 6 spans of 9.3 $\mathrm{m}$ wide and $84 \mathrm{~m}$ long, equipped with lateral ventilations of manual opening and closing in its four sides. Additionally, this model has fixed ventilations on roof in each one of the spans, ventilation areas that do not count on any type of closing for the night hours, situation that is characteristic in the Colombian greenhouses. The multiannual climatic conditions for the night hours establish that in the zone the average value of the minimum temperature was $6.79{ }^{\circ} \mathrm{C}$, with minimum values of $4.4^{\circ} \mathrm{C}$ and maximums values of $9.39{ }^{\circ} \mathrm{C}$, likewise the behavior of the wind speed shows average values lower than $1.0 \mathrm{~ms}^{-1}$.

A) Greenhouse roof

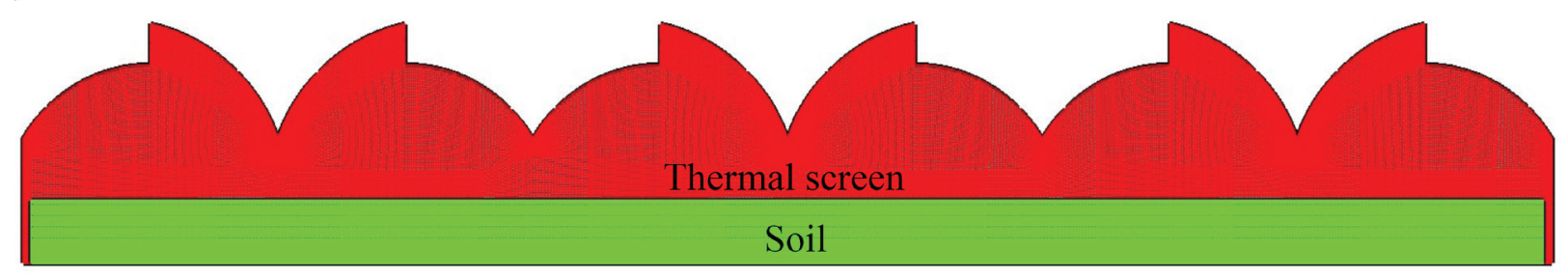

B)

\begin{tabular}{|lcr|}
\hline \multicolumn{1}{c}{ Computational domain } & Pressure - Outlet \\
\hline Air - Inlet & Symmetric & \\
& & \\
& Wall & Wreenhouse \\
\hline
\end{tabular}

Figure 1. A) detail of the greenhouse mesh and B) detail of the computational domain mesh.

\section{Model and numerical procedure}

Numerical simulations solved the equations that describe the flow behavior of a fluid between the exterior and interior environment of a greenhouse, using the second-order finite volume discretization (FVM) method. The equations of moment, mass, energy and concentration can be represented for a two-dimensional flow in steady state with the following equation:

$$
\frac{\partial \phi}{\partial t}+\frac{\partial}{\partial x_{j}}\left(u_{j} \phi\right)=\frac{\partial}{\partial x_{j}}\left(\Gamma_{\phi} \frac{\partial \phi}{\partial x_{j}}\right)+S_{\phi}
$$

where $\phi$ represents the variable of interest, in this case the vertical and horizontal components of speed $u_{j}\left(\mathrm{~m} \mathrm{~s}^{-1}\right)$ and temperature $\mathrm{T}\left({ }^{\circ} \mathrm{C}\right) . S_{\phi} y \Gamma_{\phi}$ represent the source term and the diffusion coefficient of $\phi$.
The numerical model considers the turbulence of the flow through the standard model $k-\varepsilon$. This semi-empirical model is based on the transport equations that solve turbulent kinetic energy and the dissipation of the energy by unit of volume $\varepsilon$, this model has been the most used and extensively validated in studies of air flow in greenhouses showing to be efficient with the use of computational resources and providing realistic solutions (Piscia et al., 2015). The transport equations for $\mathrm{k}$ and $\varepsilon$ can be modeled as:

$$
\frac{\partial}{\partial x}(\rho k)=\frac{\partial}{\partial x_{j}}\left[\left(\mu+\frac{\partial k}{x_{j}}\right) \frac{\partial k}{\partial x_{j}}\right]+G_{k}+G_{b}-\rho \epsilon-Y_{M}
$$

$\frac{\partial}{\partial t}(\rho \varepsilon)=\frac{\partial}{\partial x_{i}}\left[\left(\mu+\frac{\mu_{t}}{\sigma}\right) \frac{\partial \epsilon}{\partial x_{i}}\right]+\rho C_{1} S_{\epsilon}-\rho C_{2} \frac{\epsilon^{2}}{k+\sqrt{v \epsilon}}+C_{1 \epsilon \frac{\epsilon}{k}} C_{3 \epsilon} G_{b} k$ 
where $u$ is viscosity and y is turbulent viscosity in $(\mathrm{kg}$ $\left.\mathrm{m}^{-1} \mathrm{~s}^{-1}\right), G_{b}$ is turbulent kinetic energy generation due to buoyancy, $G_{k}$ is turbulent kinetic energy generation due to velocity gradients, and $\sigma_{\epsilon}$ are Prandtl's turbulent numbers for $k$ and $\varepsilon, v$ is the coefficient of kinematic viscosity, $Y_{M}$ is the fluctuating expansion in turbulence due to the global dissipation rate and $C_{1 \epsilon}, C_{2 \epsilon}, C_{\mu}, \sigma_{k}$ and $\sigma_{\epsilon}$ are constant with empirically determined values and established by default in the simulation software.

The Boussinesq model was considered to simulate and calculate variations in greenhouse air density generated by temperature changes. The buoyancy force due to differences in air density is added as a source term in the impulse equation. The presence of insect screens was modeled using equations derived from the flow of a free and forced fluid through porous materials, taking into account their main characteristics of porosity and permeability (Valera et al., 2005). These equations can be derived from the Forchheimer's equation:

$$
\frac{\partial p}{\partial x}=\frac{\mu}{K} u+\rho \frac{C f}{\sqrt{K}} u|u|
$$

where $\mathrm{u}$ is the air velocity $\left(\mathrm{m} \mathrm{s}^{-1}\right) ; \mu$ is the dynamic viscosity of the fluid $\left(\mathrm{kg} \mathrm{m}^{-1} \mathrm{~s}^{-1}\right), \mathrm{K}$ is the permeability of the medium $\left(\mathrm{m}^{2}\right)$; $\mathrm{Cf}$ is the Inertial Factor of the mesh; $\rho$ is the air density $\left(\mathrm{kg} \mathrm{m}^{-3}\right)$ and $\partial \mathrm{x}$ the thickness of the porous material (m).

The selected radiation model was the discrete ordinate (DO) with angular discretization, this allows to add the radiation as a source term in the energy equation to be modeled in semitransparent mediums as it is the case of the plastics of the greenhouse roofs. This model makes it possible to perform climate analysis in night-time conditions, simulating and resolving the phenomenon of radiation from the greenhouse floor to the outdoor environment (Montero et al., 2013). The DO model solves the general equation of radiation transfer (RTE) by the following expression:

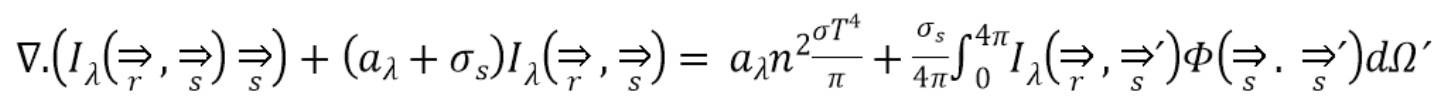

Where $I_{\lambda}$ is the intensity of radiation at a wavelength; $\vec{r}, \underset{s}{\Rightarrow}$ are the vectors that indicate the position and direction, respectively; $\underset{s}{\Rightarrow}$ is the direction vector of dispersion; $\sigma_{s}, a_{\lambda}$ are the coefficients of dispersion and spectral absorption; $n$ is the refractive index; $\nabla$ is the divergence operator; $\sigma$ is the de Stefan-Boltzmann constant $\left(5.669 \times 10^{-8} \mathrm{Wm}^{-2}{ }^{\circ} \mathrm{C}^{-4}\right)$, $\Phi, \mathrm{T}$ and $\Omega$ are the phase function, the local temperature $\left({ }^{\circ} \mathrm{C}\right)$ and the solid angle, respectively.

The semi implicit solution method for the pressurevelocity equation (SIMPLE) was applied to solve the flow field of the simulated fluid, with second order discretization schemes, this solution method has a working scheme which starts with some initial values to solve the moment equations and obtain the speed variable components, successively calculates coefficient and source terms through the pressure correction equation, calculates the speed corrections and updates the pressure and speed components to obtain the solution. For this case the solution of the numerical simulations was taken when the normalized residues of all the squares of the domain were less than $10^{-6}$ for the equations of continuity, momentum, turbulence, energy and DO intensity. The model did not include any crop and additionally, a total hermeticity of the greenhouse was assumed. These simplifications are valid since they are applied to each of the simulated cases and the errors that can be derived will have the same degree of magnitude for each scenario.

\section{Computational domain, grid size and boundary} conditions

The 2D computational domain (Figure 1B), which included a cross-section of the greenhouse and its surrounding outdoor environment, was $355 \mathrm{~m}$ wide ( $\mathrm{x}$-axis) and $50 \mathrm{~m}$ high (y-axis) and was constructed following the recommendations given by (Kim et al., 2017). In the process of mesh generation an unstructured grid of square elements is selected with a total of 671,713 elements, the density of the mesh was increased in the regions close to the screens, floor, side wall and roof which are the regions where the relevant thermal gradients are usually and which in turn were simulated with the improved wall treatment. This size was defined once a mesh refining analysis was carried out where a total of 12 squares were analyzed with a quantity of elements that varied between 91,871 and $1,104,369$, this in order to obtain an adequate precision and a total independence of the results to the size of the mesh. The mesh quality was evaluated by $\mathrm{y}^{+}$value, controlling this value in the validity range that is in the interval of $20<$ $\mathrm{y}^{+}<200$. Additionally the asymmetry factor was evaluated, where $90.8 \%$ of the active volumes exhibited a value within the range $0-0.25$, considered of excellent quality (Ansys, 2016).

The established boundary conditions considered the atmospheric characteristics of the study site and the physical properties of the materials of the greenhouse. A symmetrical type edge condition was established in the upper part of the computational domain, in the left limit an air inlet velocity was imposed with a logarithmic profile linked to the CFD numerical model using the function defined by the user (UDF), by the equation:

$$
v(y)=\frac{v^{*}}{K} \ln \left(\frac{y+y_{o}}{y_{o}}\right)
$$

Where $v(y)$ is the average wind speed at height $y$ above ground level, $y_{o}$ is the roughness of the surface that was established in $0.0161 \mathrm{~m}$ depending on the standard of response of the local terrain, $v^{*}$ is the friction velocity and $K$ is the von Karman constant with a value of 0.42 , in the right limit flow outflow region a pressure outflow condition was established. 
The lateral walls and the cover of the greenhouse were meshed as elements of thickness of $0.2 \mathrm{~mm}$, these surfaces were considered as semitransparent solids and their optical properties for infrared radiation assuming an independence of the wavelength were transmissivity 0.19 , absorption 0.69 and reflectivity 0.12 , equally for the thermal screen values were taken for these properties of $0.42,0.2$ and 1.0 for transmissivity, emissivity the reflectivity, respectively. Fixed roof ventilation zones were established as porous media and the following edge conditions were imposed, Effect Viscosity $(\alpha)=3.98 \mathrm{e}^{-9}$ and Drag Coefficient $\left(\mathrm{C}_{2}\right)$ 19185. The exchange of radiation between the greenhouse and the outside environment was simulated by considering the sky as a black body at an equivalent temperature. ( $\mathrm{T}_{\text {sky }}$, in degrees ${ }^{\circ} \mathrm{K}$ ), for clear sky conditions using the ratio established by Swinbank (1963):

$$
T_{\text {cielo }}=0.0552 T_{a m b}^{1.5}
$$

This expression represents a direct model that estimates the temperature of the sky through the value of the ambient air temperature $\left(\mathrm{T}_{\mathrm{amb}}\right)$. For the cloudy sky condition was established using an evolution of the Swinbank model proposed by Fuentes (1987):

$$
T_{\text {cielo }}=0.037356 T_{a m b}^{1.5}+0.32 T_{a m b}
$$

The lower part of the computational domain corresponding to the greenhouse floor was modeled as an opaque solid and additionally it was established a limit condition of heat transfer to the interior of the greenhouse, procedure similar to the one established in the work developed by Piscia et al. (2012).

Collection of experimental data and validation of the CFD model

The collection of experimental data for the purpose of validating the CFD model was carried out between March 25 and May 3, 2017. The data collection was established for a recording frequency of ten minutes with a meteorological monitoring equipment assembled out inside the greenhouse and in its external environment at a proximity of $50 \mathrm{~m}$. The meteorological variables for night hours outside the greenhouse that are necessary to fodder the CFD model are air temperature, wind speed and direction and were recorded by a Vantage Pro2 climate system (Davis Instruments, Hayward, CA, EE. UU.). Inside the greenhouse at a height of $1.7 \mathrm{~m}$ above ground level (y-axis) and above the cross section (x-axis), a total of 18 copper thermocouples used to measure dry bulb temperatures were uniformly distributed every $3 \mathrm{~m}$ and stored in a data logger (Cox-Tracer Junior, Escort DLS, Edison, NJ, EE. UU.) and in the central zone of the greenhouse in the ground a heat flow sensor (Hukseflux HFP01SC, Campbell, Scientific, Delft, The Netherlands). Once the experimental data had been processed, simulations were developed for hours 20, 0 and 5 using as boundary conditions the average outdoor meteorological conditions recorded during the experimentation phase and the value of the heat flow measured in the interior soil of the greenhouse (Table 1). Once the process phase of the simulations was completed, the simulated temperature data were extracted from the coordinates $(\mathrm{x}, \mathrm{y})$ of each measurement point and compared with those obtained experimentally through the following criteria of better adjustment, mean absolute error, mean quadratic error and determination coefficient (MAE, RMSE, $\mathrm{R}^{2}$ ) and are calculated using the following expressions.

$$
\begin{aligned}
& M A E=\frac{1}{N} \sum_{i=1}^{N} \frac{\left|T m_{i}-T s_{i}\right|}{T_{m i}} * 100 \\
& R M S E=\sqrt{\sum_{i=1}^{N} \frac{\left|T m_{i}-T s_{i}\right|^{2}}{N}} \\
& R^{2}=1-\frac{\sum_{i=1}^{N}\left|T m_{i}-T s_{i}\right|^{2}}{\sum_{i=1}^{N}\left|T m_{i}-\overline{T m}\right|^{2}}
\end{aligned}
$$

\begin{tabular}{|c|c|c|c|c|c|}
\hline Hour & $\begin{array}{l}T_{\text {amb }} \\
\left({ }^{\circ} \mathrm{C}\right)\end{array}$ & $\begin{array}{l}\mathbf{T}_{\text {Sky }} \\
\left({ }^{\circ} \mathbf{C}\right)\end{array}$ & $\begin{array}{l}\text { Wind speed } \\
\qquad\left(\mathrm{m} \mathrm{s}^{-1}\right)\end{array}$ & Wind direction $\quad\left(^{\circ}\right)$ & Soil heat flow \\
\hline 20 & 8.65 & -5.4 & 0.74 & 109.2 & 14.24 \\
\hline 0 & 6.29 & -8.3 & 0.67 & 111.3 & 11.76 \\
\hline 5 & 5.89 & -8.9 & 0.68 & 109.9 & 8.65 \\
\hline
\end{tabular}

Where $N$ is the number of samples, $T m_{i} y T s_{i}$ are the measured and simulated temperature values at point $\mathrm{i}$ respectively and $\overline{\mathrm{Tm}}$ is the mean of the observed values.

Table 1. Average weather conditions for selected validation hours.

\section{Simulated scenarios}

The numerical simulations developed once the CFD model was validated were grouped into three scenarios, assuming three conditions of the thermal behavior of the study area, minimum night mean temperature (S1), night mean temperature (S2) and maximum night mean temperature (S3), two specific sky conditions, clear (C1) and cloudy (C2) and four management configurations, the reference (M1), the use of a porous mesh in fixed roof vents (M2), the use of a thermal screen at a height of 2 above ground level and above the top of the crop (M3) and a combination of M2 and M3 (M4), these conditions were combined and a total of 24 stationary state simulations were performed (Table 2). 
Table 2. Definition of the scenarios selected for the simulations.

\begin{tabular}{|c|c|c|c|c|}
\hline Scenario & Simulation & Wind speed $\left(\mathrm{m} \mathrm{s}^{-1}\right)$ & Air temperature $\left({ }^{\circ} \mathrm{C}\right)$ & Sky temperature $\left({ }^{\circ} \mathrm{C}\right)$ \\
\hline \multirow{2}{*}{ S1 } & $\begin{array}{l}\text { S1C1M1 S1C1M2 } \\
\text { S1C1M3 S1C1M4 }\end{array}$ & 0.8 & 4.4 & -17.90 \\
\hline & $\begin{array}{l}\text { S1C2M1 S1C2M2 } \\
\text { S1C2M3 S1C2M4 }\end{array}$ & 0.8 & 4.4 & -10.76 \\
\hline \multirow{2}{*}{ S2 } & $\begin{array}{l}\text { S2C1M1 S2C1M2 } \\
\text { S2C1M3 S2C1M4 }\end{array}$ & 0.8 & 6.79 & -14.60 \\
\hline & $\begin{array}{l}\mathrm{S} 2 \mathrm{C} 2 \mathrm{M} 1 \mathrm{~S} 2 \mathrm{C} 2 \mathrm{M} 2 \\
\mathrm{~S} 2 \mathrm{C} 2 \mathrm{M} 3 \mathrm{~S} 2 \mathrm{C} 2 \mathrm{M} 4\end{array}$ & 0.8 & 6.79 & -7.75 \\
\hline \multirow{2}{*}{ S3 } & $\begin{array}{l}\text { S3C1M1 S3C1M2 } \\
\text { S3C1M3 S3C1M4 }\end{array}$ & 0.8 & 9.39 & -10.99 \\
\hline & $\begin{array}{l}\mathrm{S} 3 \mathrm{C} 2 \mathrm{M} 1 \mathrm{~S} 3 \mathrm{C} 2 \mathrm{M} 2 \\
\mathrm{~S} 3 \mathrm{C} 2 \mathrm{M} 3 \mathrm{~S} 3 \mathrm{C} 2 \mathrm{M} 4\end{array}$ & 0.8 & 9.39 & -4.47 \\
\hline
\end{tabular}

\section{Results and discussion}

\section{Model validation}

The temperature value measured and simulated for each of validated hours showed a behavior in the cross section of the greenhouse with a very similar trend (Figure 2). The comparison of the experimental and simulated temperature data obtained in each sampling point, showed values of MAE and RMSE of 0.55 and $0.53^{\circ} \mathrm{C}$ for hour $20,0.30$ and $0.29^{\circ} \mathrm{C}$ for hour 0 and 0.18 and $0.17^{\circ} \mathrm{C}$ for hour 5 , values that can be considered low and are within the ranges obtained in similar studies as the one developed by Espinal-Montes et al. (2015).

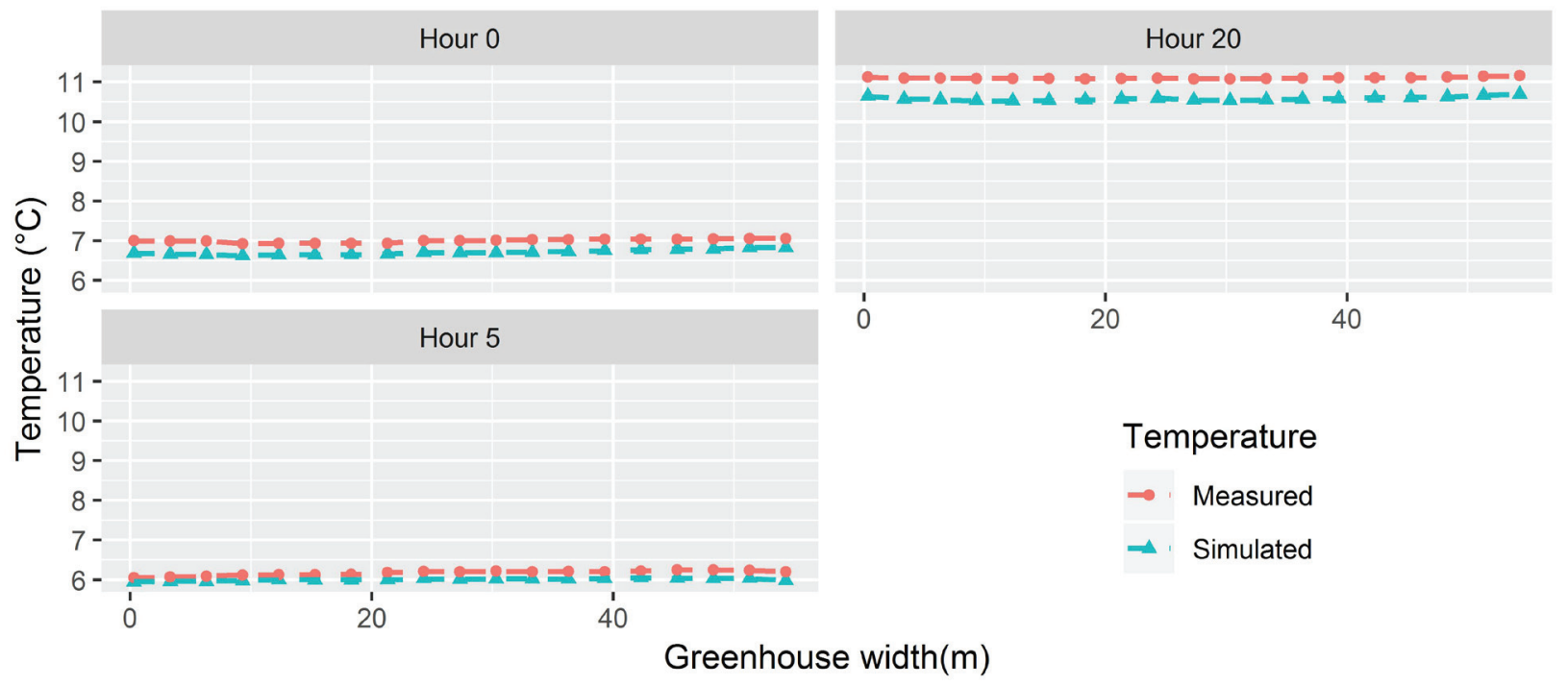

Figure 2. Profiles of the mean value of the measured and simulated temperature.

The 1:1 scatter plots between the measured and simulated values for each hour (Figure 3) and the determination coefficient values $\left(\mathrm{R}^{2}\right)$ obtained between the data sets were $0.90,0.83$ and 0.81 for the 20,0 and 5 hours respectively, performance that together with those obtained for MAE and RMSE, allow to conclude that the numerical model predicts in a satisfactory way the nocturnal thermal behavior and can be used to evaluate optimization strategies. 


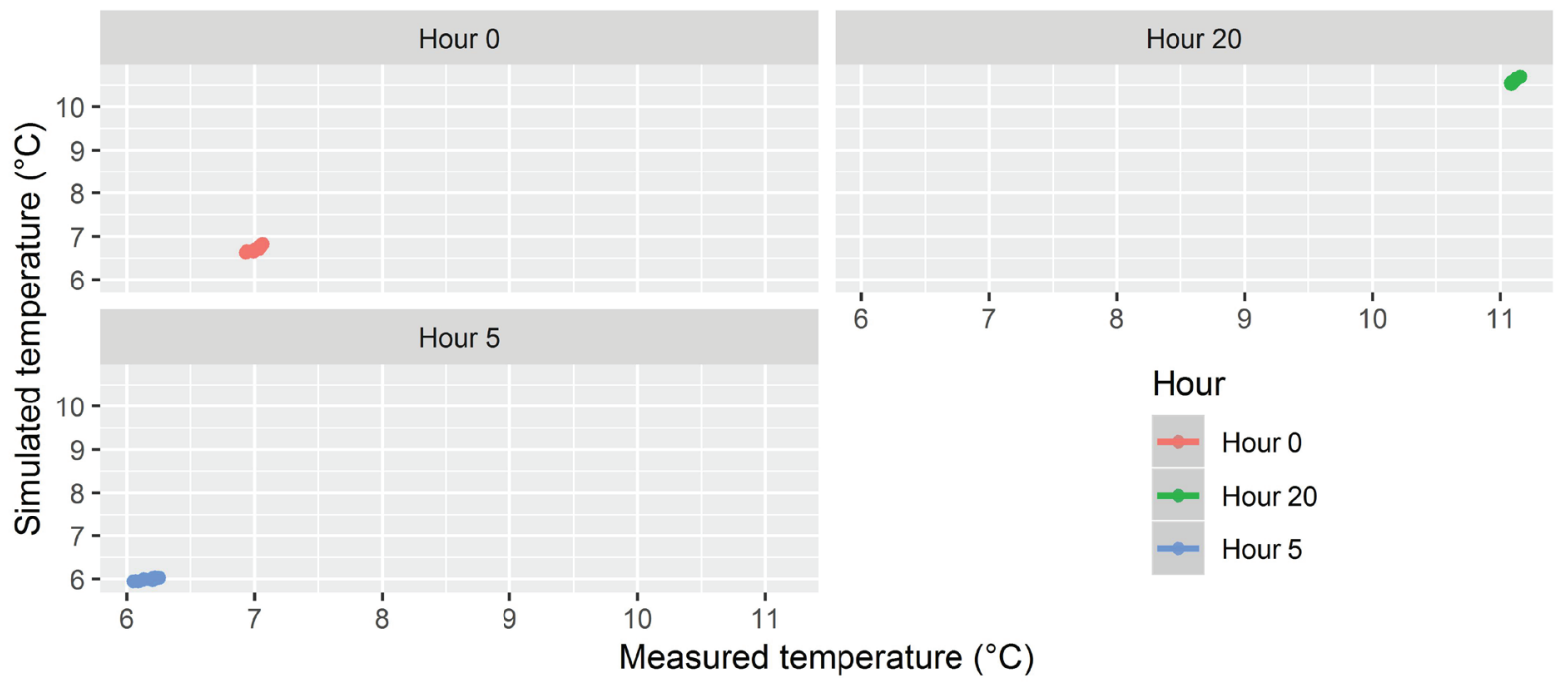

Figure 3. Scatter plots 1:1 between measured and simulated temperature.

\section{Scenario S1}

\section{Air flow and thermal distribution fields}

\section{Nights with clear skies (C1)}

The flow and thermal distribution patterns inside the greenhouse (Figure 4), obtained in the numerical simulations for this scenario, show flow patterns that are governed by the wind effect of natural ventilation due to the air currents that enter the greenhouse through the roof windows of each building, this air enters the greenhouse and mixes with the currents generated near the floor surface where the thermal gradients induce flotation movements inside the greenhouse, and then comes out through some of the roof vents that function as air entry and exit areas, as previously also reported by Majdoubi et al. (2016).

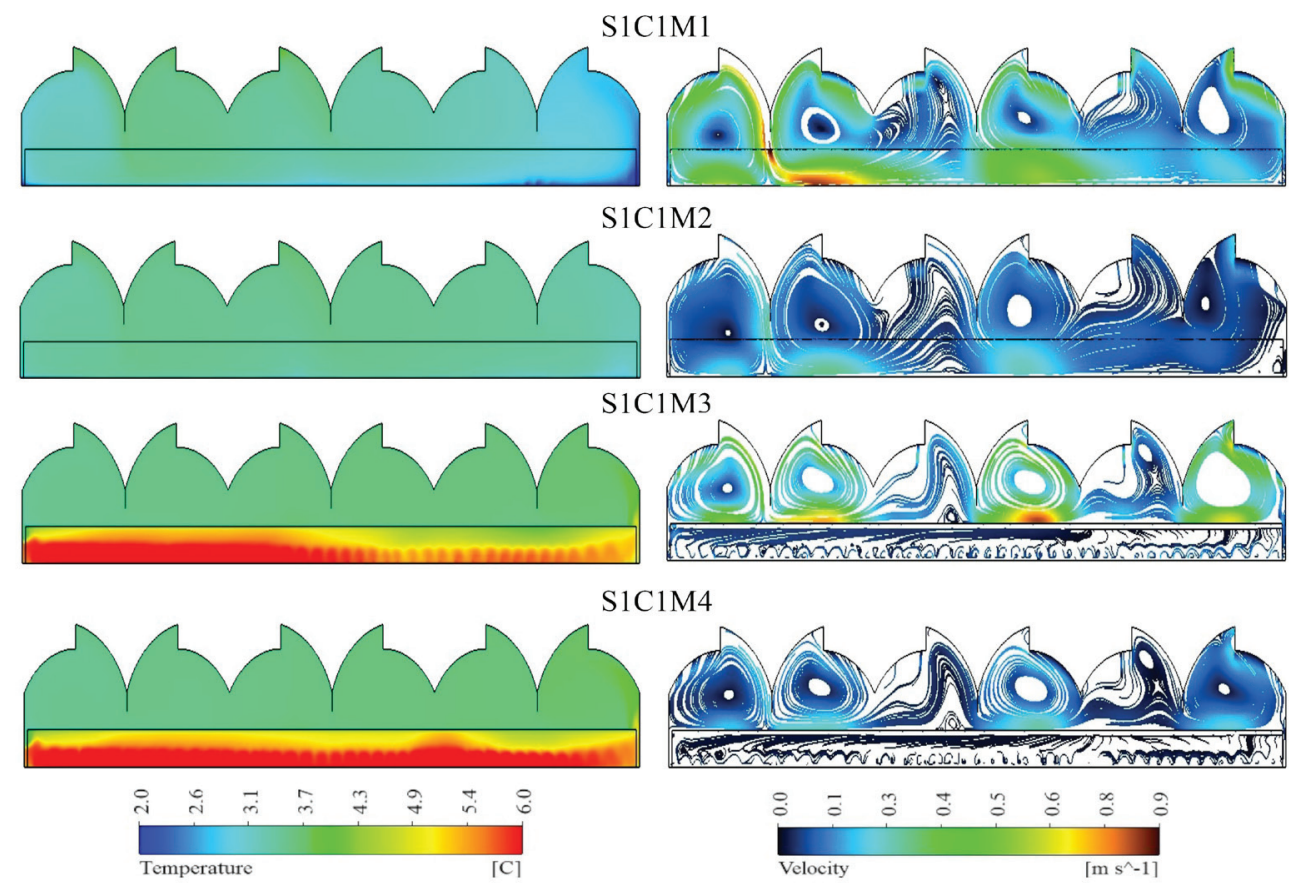

Figure 4. Simulated temperature $\left({ }^{\circ} \mathrm{C}\right)$ distribution contour and airflow pattern $\left(\mathrm{ms}^{-1}\right)$ for S1C1M1, S1C1M2, S1C1M3 y S1C1M4.

The air flow patterns showed the formation of 4 convective cells, the first is generated under the volume of air in span 1, the second is a movement cell between span 2 and 3 , the third between span 4 and 5 and the fourth in span
6 (Figure 4). The presence of the thermal screen generates a variation in the air flow pattern in the lower zone to this one, just where the crops are established, this pattern shows a series of convective movements from the ground towards 
the upper part of the thermal screen and that move from the windward side wall towards the leeward side zone at low speeds, also a horizontal flow is observed in the adjacent area to the lower face of the thermal screen, this flow simultaneously generates a heat dragging that propitiates a heterogeneous thermal behavior with temperature values of $0.5^{\circ} \mathrm{C}$ lower than the average behavior of this region (Figure 4).

The average velocity values obtained at $1.7 \mathrm{~m}$ above ground level and above the greenhouse cross section were $0.27,0.17,0.031$ and $0.017 \mathrm{~m} \mathrm{~s}^{-1}$ for S1C1M1, S1C1M2, $\mathrm{S} 1 \mathrm{C} 2 \mathrm{M} 3$ and S1C2M4 respectively, these reductions in the average velocity values obtained in each simulation are influenced by the presence of the porous screen and the thermal screen respectively. The comportment of the temperature variable also showed variations showing a positive effect principally due to the presence of the thermal screen, the average values of temperature obtained in the culture zone were $3.28,3.84,5.72$ and $5.96{ }^{\circ} \mathrm{C}$ for S1C1M1, S1C1M2, S1C2M3 and S1C2M4. This allowed to establish that the presence of the porous screen S1C1M2 and the presence of the thermal screen $\mathrm{S} 1 \mathrm{C} 2 \mathrm{M} 3$ generate thermal increases of 17.07 and $74.39 \%$ related to the reference scenario $\mathrm{S} 1 \mathrm{C} 1 \mathrm{M} 1$, while the combined use of M2 and M3 would generate a thermal increase of $81.7 \%$.

The nocturnal temperature values obtained for this condition are below the minimum recommended for rose production which, depending on the cultivar, usually ranges between 14 and $18{ }^{\circ} \mathrm{C}$ (Reid, 2008). Although due to the number of existing rose varieties it is difficult to establish the negative effects generated by subjecting the crop to such low temperatures, it is clear that, if there is a reduction in yields in quantity and quality, mainly due to the increase in stems with the presence of bull head flowers and on the other hand under these temperature regimes, the plant usually has shorter roots and thicker factors that can put at risk the structural stability of the plant and the processes of water and nutrient uptake (De Hoog, 2001). Additionally, in order to determine whether the phenomenon of thermal inversion occurs, the thermal differential values between the interior and exterior of the greenhouse were calculated $\left(\Delta \mathrm{T}=\mathrm{T}_{\text {internal mean }}-\mathrm{T}_{\text {external mean }}\right)$, obtaining values of -1.11 , $-0.55,1.35$ and $1.56{ }^{\circ} \mathrm{C}$ for S1C1M1, S1C1M2, S1C2M3 and S1C2M4 respectively, with which it is observed that under the simulated conditions, the first two scenarios generate thermal inversion inside the greenhouse.

\section{Cloudy sky nights (C2)}

The airflow distribution fields for this condition show a comportment similar to that discussed in the previous scenario, although there are some differences in the M3 and M4 configurations, where movements are observed in the lower zone of the thermal screen in warehouses 5 and 6 with ascending displacement from the surface of the ground towards the thermal screen and additionally the horizontal flow that generated thermal heterogeneity in $\mathrm{C} 1$ is not observed (Figure 5). The mean wind speed values obtained in the area where the crops are established were $0.26,0.19,0.046$ and $0.041 \mathrm{~m} \mathrm{~s}^{-1}$ for S1C2M1, $\mathrm{S} 1 \mathrm{C} 2 \mathrm{M} 2, \mathrm{~S} 1 \mathrm{C} 2 \mathrm{M} 3$ and S1C2M4 respectively, while the mean temperature values were 5.01, 5.48, 8.49 and 8.81 ${ }^{\circ} \mathrm{C}$ for these same scenarios, again demonstrating the positive thermal effects of both thermal screens and the porous mesh, for this case it is also observed that a more homogeneous thermal distribution is obtained, in the lower zone of the thermal screen (Figure 5).
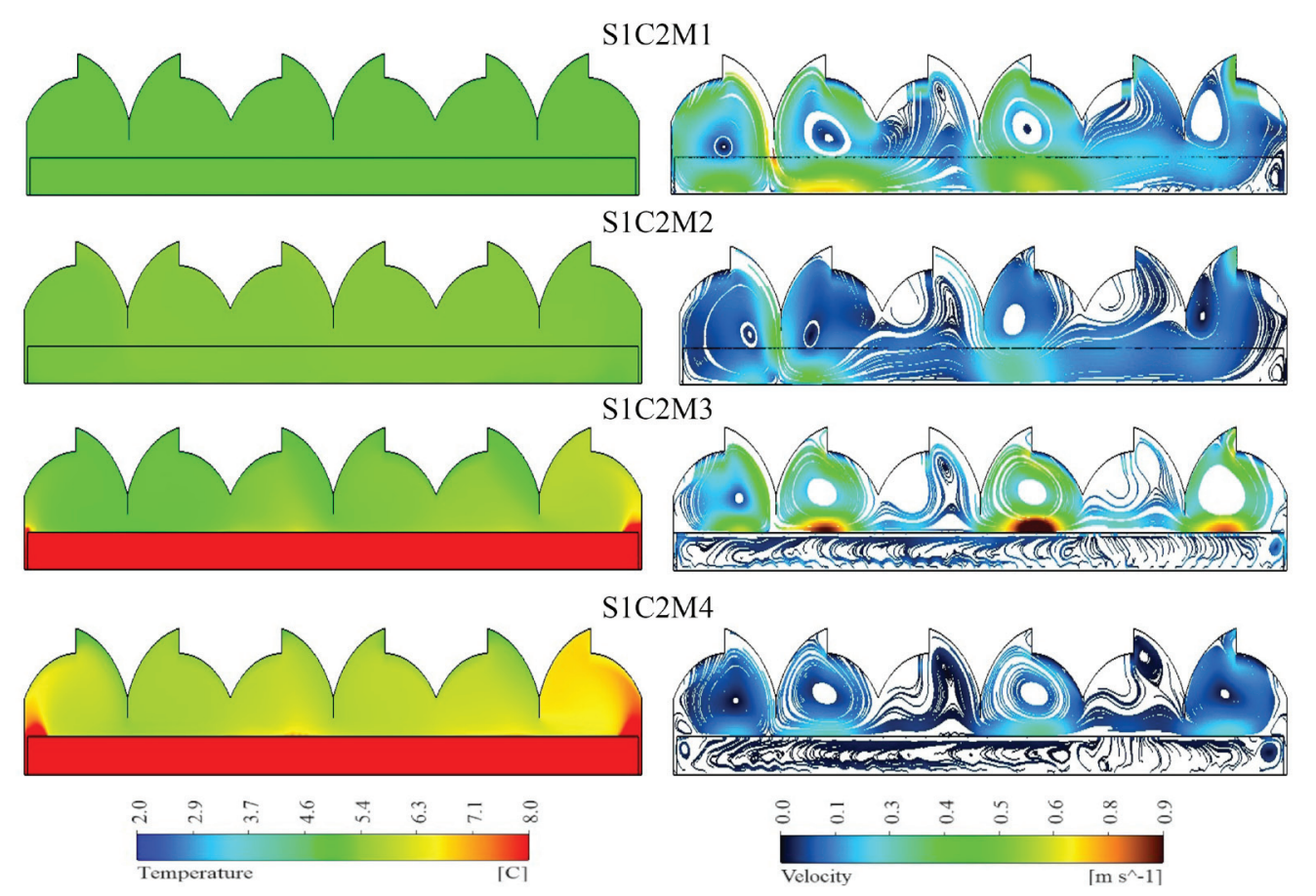

Figure 5. Simulated temperature $\left({ }^{\circ} \mathrm{C}\right)$ distribution contour and airflow pattern $\left(\mathrm{ms}^{-1}\right)$ for S1C2M1, S1C2M2, S1C2M3 y S1C2M4. 
The $\Delta \mathrm{T}$ values obtained were $0.61,1.08,4.09$ and 4.4 ${ }^{\circ} \mathrm{C}$, these conditions of higher thermal value and no thermal inversion, are influenced by the condition of the cloudy sky which generates less heat loss by infrared radiation compared to clear sky conditions, allowing a gradually higher thermal behavior inside the greenhouse.

\section{Scenario S2}

\section{Air flow and thermal distribution fields}

Nights with clear skies (C1)

In the flow patterns obtained for this simulation, there are no major differences compared to scenario S1 (Figure $6)$. The average velocity values in the cultivation zone for $\mathrm{S} 2 \mathrm{C} 1 \mathrm{M} 1$ to $\mathrm{S} 2 \mathrm{C} 1 \mathrm{M} 1$ were $0.29,0.19,0.035$ and $0.025 \mathrm{~m}$ $\mathrm{S}^{-1}$ in their order, values that are slightly higher than those obtained in S1, increase that can be generated by a greater expression of the effect of buoyancy influenced by a higher value of ambient temperature outdoors. In terms of thermal performance, an area with a lower temperature value is again observed in the adjacent area of the thermal screen, favored by a horizontal flow from the windward side wall to span number 4 (Figure 6).

The average temperature values obtained in the cultivation area were $5.99,6.25,8.44$ and $9.11{ }^{\circ} \mathrm{C}$, which generates $\Delta \mathrm{T}$ values of $-0.79,-0.53,1.65$ and $2.32{ }^{\circ} \mathrm{C}$, showing that under the M1 and M2 configurations there is a thermal inversion, while the M3 and M4 configuration limit the presence of this phenomenon and generate a thermal increase of 39.27 and $49.58 \%$ on the reference scenario S2C1M1.

\section{Cloudy sky nights (C2)}

The main difference in the airflow pattern for these conditions occurred in the cultivation zone of the S2C2M3 simulation, where the generation of a convective cell is observed between the windward side wall and the middle zone of span number 1, a cell that moves from the soil surface to the thermal screen and generates a region with $2{ }^{\circ} \mathrm{C}$ lower than that obtained in the cross section of the greenhouse (Figure 7).

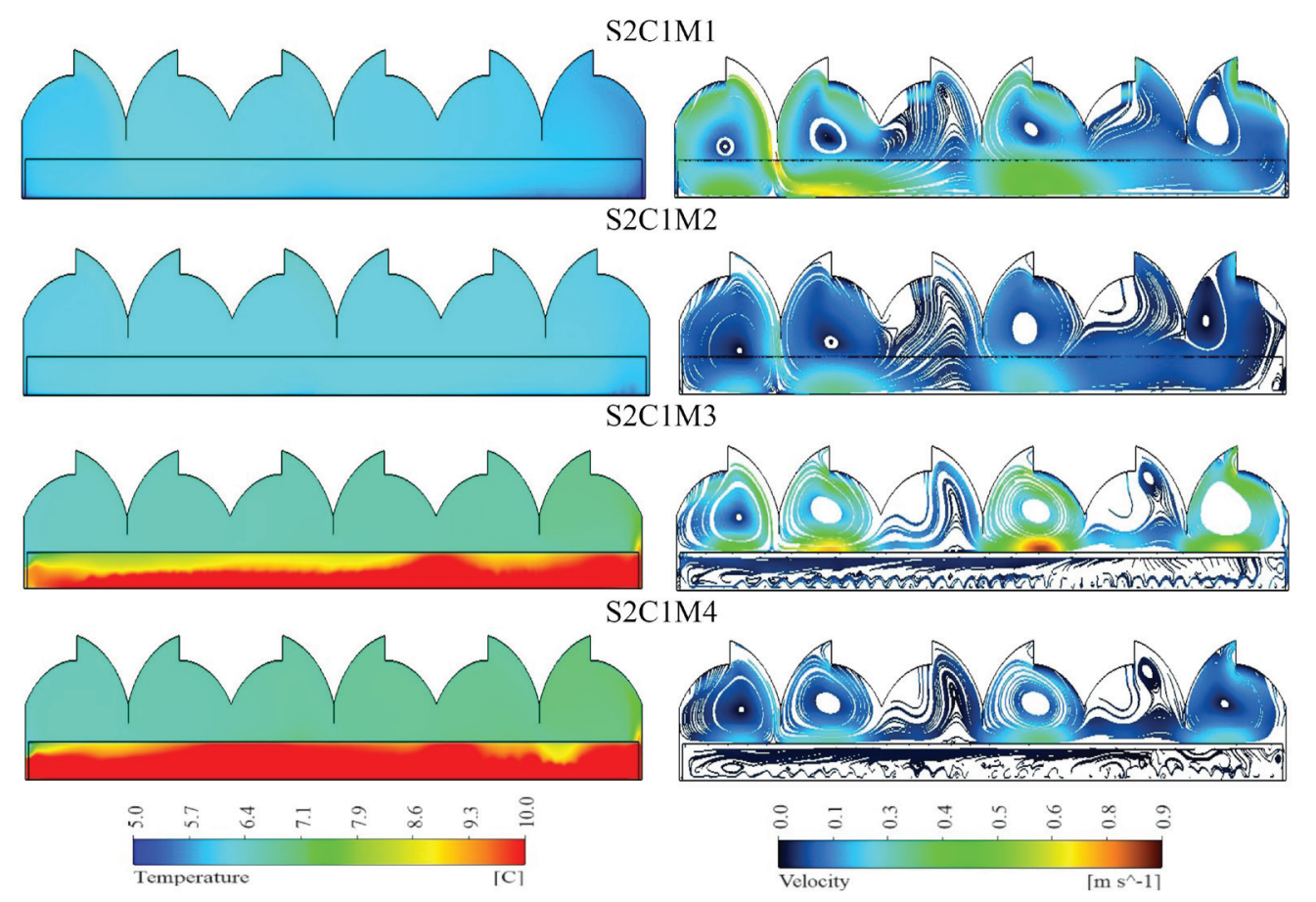

Figure 6. Simulated temperature $\left({ }^{\circ} \mathrm{C}\right)$ distribution contour and airflow pattern $\left(\mathrm{ms}^{-1}\right)$ for S2C1M1, S2C1M2, S2C1M3 y S2C1M4. 


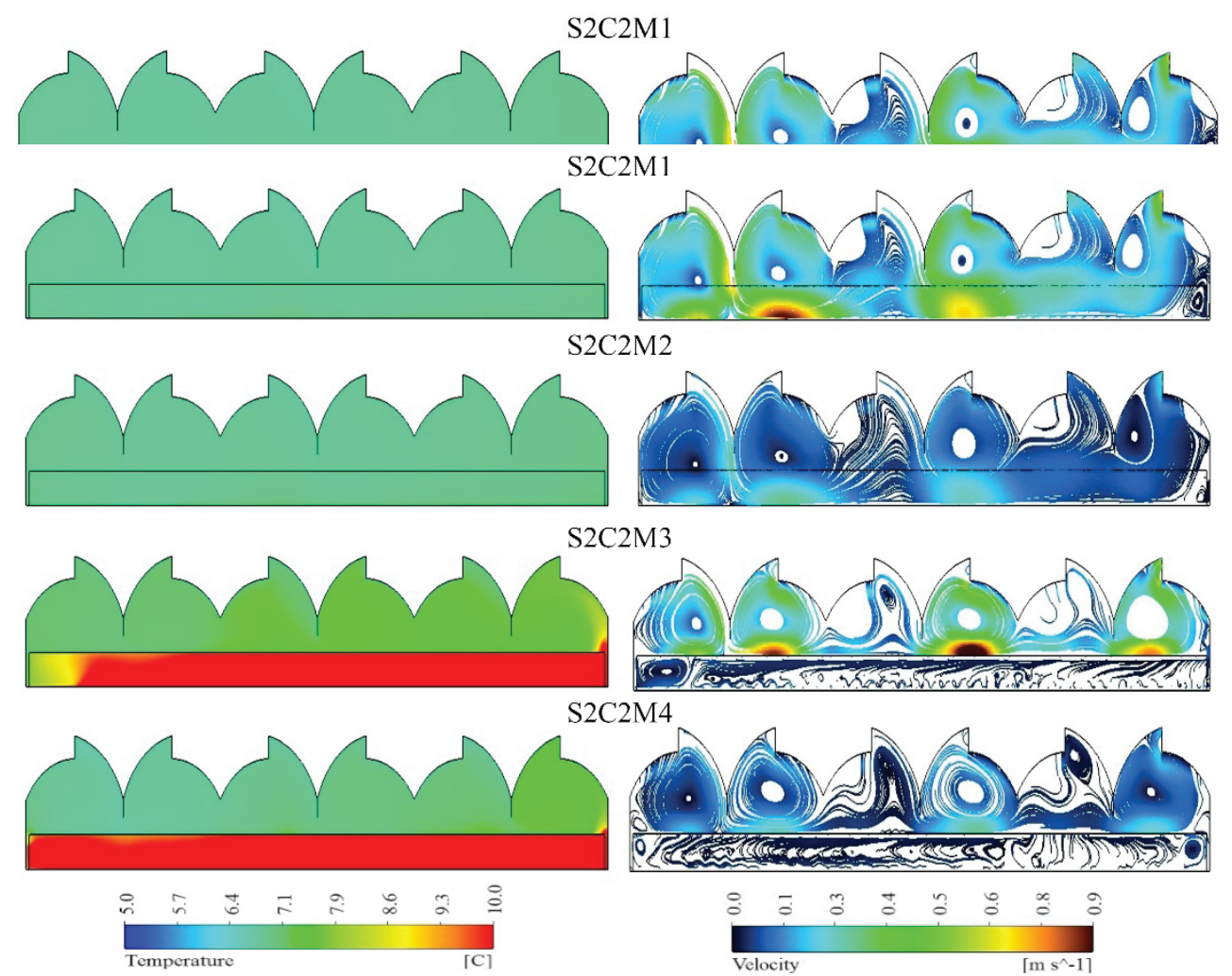

Figure 7. Simulated temperature $\left({ }^{\circ} \mathrm{C}\right)$ distribution contour and airflow pattern $\left(\mathrm{ms}^{-1}\right)$ for S2C2M1, S2C2M2, S2C2M3 y S2C2M4.

The average values of wind speed in the cultivation area were $0.32,0.19,0.035$ and $0.029 \mathrm{~m} \mathrm{~s}^{-1}$ for $\mathrm{S} 2 \mathrm{C} 2 \mathrm{M} 1$, $\mathrm{S} 2 \mathrm{C} 2 \mathrm{M} 2, \mathrm{~S} 2 \mathrm{C} 2 \mathrm{M} 3$ and $\mathrm{S} 2 \mathrm{C} 2 \mathrm{M} 3$ respectively. The thermal comportment showed a homogeneity in the simulated cases with the exception of the one in M3, the average temperature values obtained were 7.18 , 7.32, 10.83 and $11.02{ }^{\circ} \mathrm{C}$, with which values of $\Delta \mathrm{T}$ of 0 were obtained.39, $0.53,4.04$ and $4.23{ }^{\circ} \mathrm{C}$ in their order for $\mathrm{S} 2 \mathrm{C} 2 \mathrm{M} 1$ to $\mathrm{S} 2 \mathrm{C} 2 \mathrm{M} 4$, obtaining a thermal gain with M3 and M4 of 50.83 and $53.48 \%$ compared to M1 and additionally observing that the phenomenon of thermal inversion is not presented.

\section{Scenario S3}

Air flow and thermal distribution fields

\section{Nights with clear skies (C1)}

The airflow patterns for this scenario again show convective performance, which move between the roof ventilation openings and the greenhouse floor in M1 and M2, while for M3 and M4 the differentiated performance are observed at the top and bottom of the thermal screen (Figure 8). At the same time these movement patterns maintain the main characteristics obtained in S1 and S2. The mean velocity values obtained in the cultivation zone were $0.25,0.14,0.032$ and $0.023 \mathrm{~m} \mathrm{~s}^{-1}$ for S3C1M1 to $\mathrm{S} 3 \mathrm{C} 1 \mathrm{M} 4$ respectively.
The thermal performance (Figure 8) shows that for M3 there is a heterogeneous comportment between the windward wall and span number 2, comportment generated by the air flow pattern generated in that zone. For these S3 simulation conditions average temperature values at $1.7 \mathrm{~m}$ above ground level of $8.27,8.56,12.04$ and $12.46{ }^{\circ} \mathrm{C}$ were obtained, so the values of $\Delta \mathrm{T}$ were $-1.09,-0.83,2.65$ and $3.07{ }^{\circ} \mathrm{C}$ for S3C1M1, S3C1M2, S3C1M3 and S3C1M4.

The results showed that for clear sky conditions $\mathrm{C} 1$, in all scenarios S1-S3 and a standard greenhouse configuration M1 and for the M2 configuration, there will always be the phenomenon of thermal inversion with $\Delta \mathrm{T}$ values between -0.53 and $-1.11{ }^{\circ} \mathrm{C}$, this is undoubtedly not a desirable comportment inside a greenhouse, therefore the search for alternatives for nighttime climate optimization should focus on obtaining productive gains that lead to improve the quality of rose production in Colombia.

\section{Cloudy sky nights (C2)}

The mean velocity of the airflow pattern obtained for M1-M4 at the height of the cultivation zone was 0.27 , $0.22,0.038$ and $0.027 \mathrm{~m} \mathrm{~s}^{-1}$ (Figure 9). These air movement patterns generated average temperatures in this zone of $10.32,10.61,14.55$ and $15.12^{\circ} \mathrm{C}$ respectively for $\mathrm{M} 1, \mathrm{M} 2$, $\mathrm{M} 3$ and M4, with $\Delta \mathrm{T}$ values of $0.93,1.22,5.16$ and $5.73^{\circ} \mathrm{C}$, values that are like those obtained in the study carried out by Montero et al. (2013). 


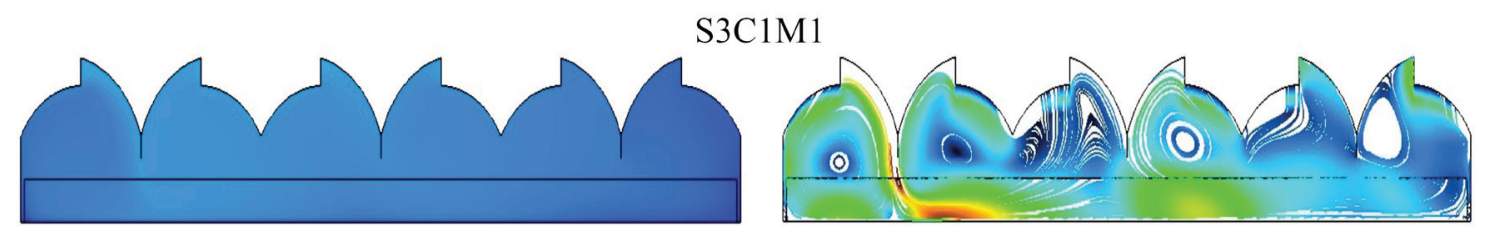

$\mathrm{S} 3 \mathrm{C} 1 \mathrm{M} 2$
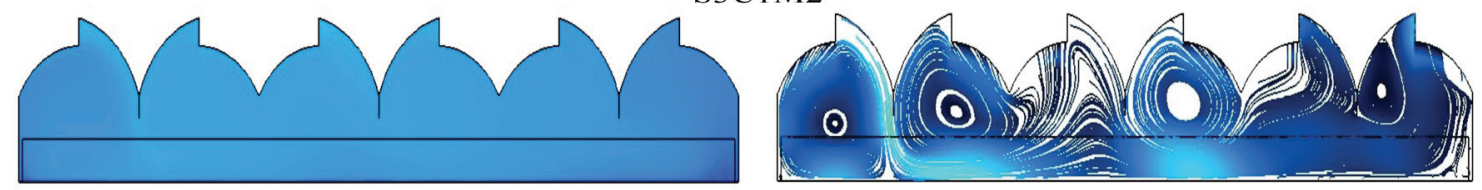

$\mathrm{S} 3 \mathrm{C} 1 \mathrm{M} 3$

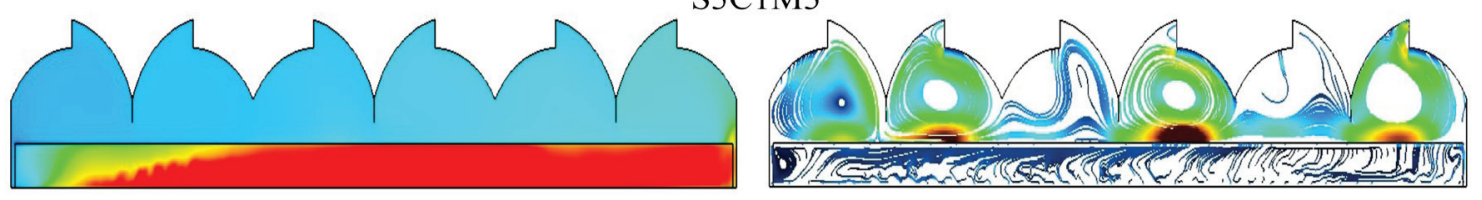

$\mathrm{S} 3 \mathrm{C} 1 \mathrm{M} 4$
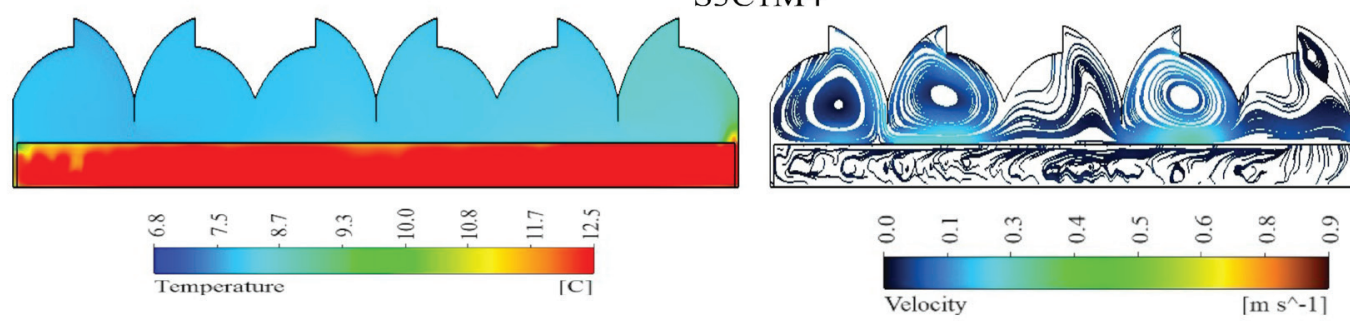

Figure 8. Simulated temperature $\left({ }^{\circ} \mathrm{C}\right)$ distribution contour and airflow pattern $\left(\mathrm{ms}^{-1}\right)$ for S3C1M1, S3C1M2, S3C1M3 y S3C1M4.

$\mathrm{S} 3 \mathrm{C} 2 \mathrm{M} 1$

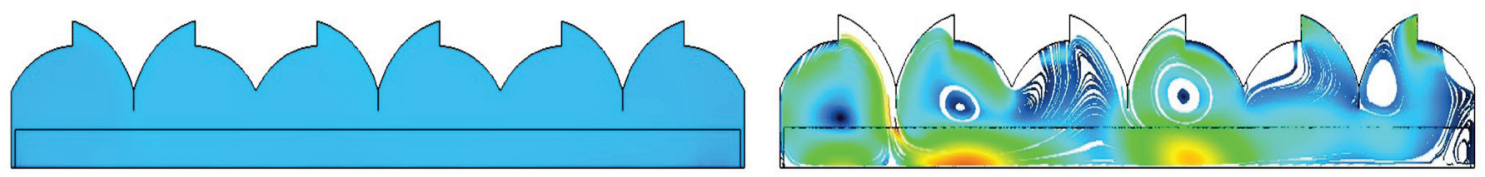

$\mathrm{S} 3 \mathrm{C} 2 \mathrm{M} 2$

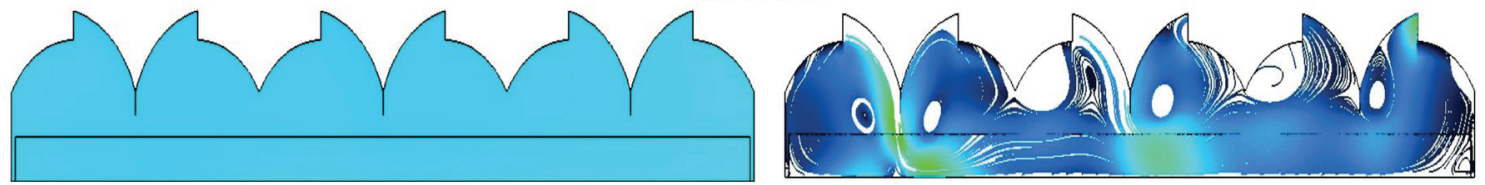

$\mathrm{S} 3 \mathrm{C} 2 \mathrm{M} 3$

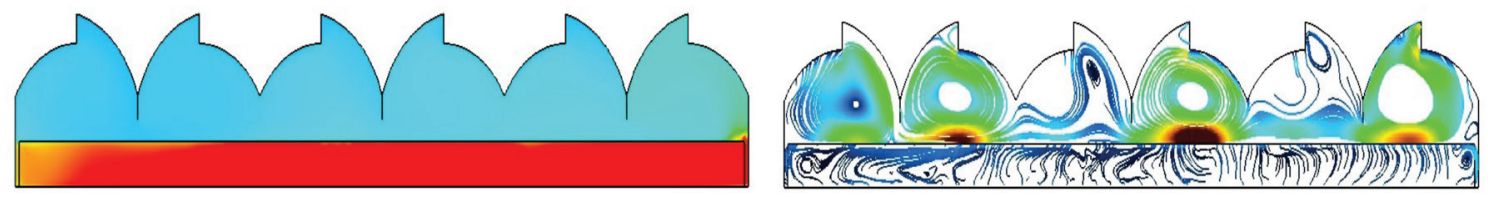

$\mathrm{S} 3 \mathrm{C} 2 \mathrm{M} 4$
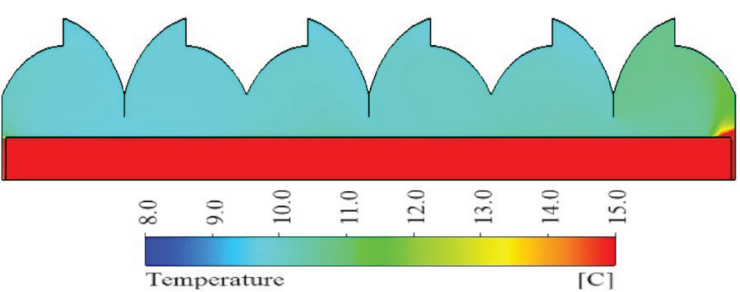

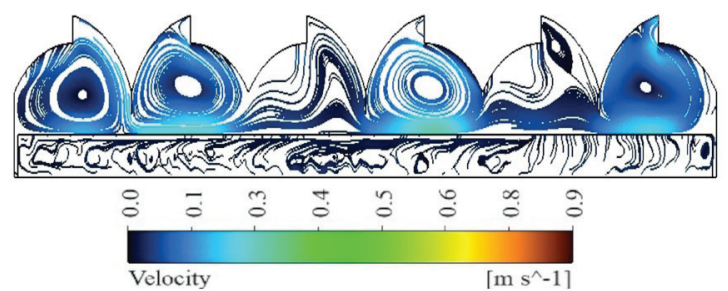

Figure 9. Simulated temperature $\left({ }^{\circ} \mathrm{C}\right)$ distribution contour and airflow pattern $\left(\mathrm{ms}^{-1}\right)$ for S3C2M1, S3C2M2, S3C2M3 y S3C2M4. 
These results allow to conclude that the use of the thermal screen and the porous screen are a viable alternative for the optimization of the nocturnal climate in this type of greenhouse and that it favors the generation of thermal conditions that approach the optimal conditions of temperature $14{ }^{\circ} \mathrm{C}$ for the production of rose and limits the presence of the phenomenon of thermal inversion under any condition of sky $\mathrm{C} 1$ and $\mathrm{C} 2$. We can also conclude that for the clear sky condition $\mathrm{C} 1$ the proposed alternatives $\mathrm{M} 3$ and M4 are alternatives that allow on the one hand to limit the energy loss inside the greenhouse which leads to thermal patterns with positive values of $\Delta \mathrm{T}$ between 1.35 and 3.07 ${ }^{\circ} \mathrm{C}$. It should also be mentioned that the alternatives studied can be complemented with the use of other types of passive heating strategies that store sensible heat, for example the use of plastic sleeves filled with water heated in a solar way (Gourdo et al., 2019) or bedrock systems (Bazgaou et al., 2018), systems that have been shown to be efficient in plastic greenhouses by increasing the temperature values between 2.6 and $3.2^{\circ} \mathrm{C}$, which would allow optimizing the night microclimate especially for scenarios S1 and S2.

\section{Conclusions}

This study used a numerical simulation model CFD 2D successfully validated experimentally, which allowed a study of alternatives of three passive alternatives of nocturnal microclimatic optimization for a multitunnel gothic greenhouse proposed for rose production. The results allowed to verify that for the conditions of clear sky the greenhouses of plastic cover do not have a high capacity to store the thermal energy increased during the day in the hours of the night, propitiating the appearance of the phenomenon of thermal inversion, on the other hand, the use of thermal screens extended over the upper part of the crop combined with the use of porous screens in the roof ventilation areas proved to be viable alternatives that allow higher temperature values to be generated inside the greenhouse with respect to the external environment of 1.35 and $3.07{ }^{\circ} \mathrm{C}$ for the clear sky condition and 5.04 and $5.73{ }^{\circ} \mathrm{C}$ for the cloudy sky condition. Therefore, the general conclusion is that the use of the proposed alternatives generates better thermal conditions than the Colombian standard scenario, which could generate benefits in rose production both in quality and quantity, contributing to the sustainability of the Colombian ornamental sector.

\section{Author contribution}

E.A.V.M. 0000-0003-1860-5932: idea of creation, development of numerical simulations, data analysis and collection, preparation of manuscript, results analysis. C.R.B.A. ${ }^{0000-0003-0230-326 x}$ : lead and install the experiment, prepare the manuscript, results analysis.

\section{Acknowledgements}

The present study was funded by the Sistema General de Regalías and the Gobernación de Cundinamarca through the project "Fortalecimiento de la competitividad del sector floricultor colombiano mediante el uso de ciencia, tecnología e innovación aplicadas en el departamento de Cundinamarca" code: BPIN2013000100217.

\section{References}

ANSYS, 2016. User Manual, Knowledge Creation Diffusion Utilization Ansys ICEM CFD. 2016. DOI: https://doi.org/10.1016/j.joen.2015.02.033. Accessed May 22, 2019.

BAEZA， E.J.;PÉREZ-PARRA， J.J.; MONTERO， J.I.; BAILEY, B.J.; LÓPEZ, J.C.; GÁZQUEZ, J.C. Analysis of the role of sidewall vents on buoyancy-driven natural ventilation in parral-type greenhouses with and without insect screens using computational fluid dynamics. Biosystems Engineering, v.104, n.1, p.86-96. 2009. DOI: https://doi.org/10.1016/j.biosystemseng.2009.04.008

BAZGAOU, A.; FATNASSI, H.; BOUHROUD, R.; GOURDO, L.; EZZAERI, K.; TISKATINE, R.; DEMRATI, H.; WIFAYA, A.; BEKKAOUI, A.; AHAROUNE, A.; BOUIRDEN, L. An experimental study on the effect of a rock-bed heating system on the microclimate and the crop development under canarian greenhouse. Solar Energy. v.176, n.1, p.42-50. 2018. DOI: https://doi.org/10.1016/j. solener.2018.10.027

DE HOOG, J.. Handbook for modern greenhouse rose cultivation. Applied Plant Research. International Cut Flower Growers Association. 2001. Available at: $<$ https:// pdfs.semanticscholar.org/0ea7/8bc9762e79260ec6306831 570bb2b0eabc91.pdf>. Accessed June 12, 2019.

DHIMAN, M.; SETHI, V.P.; SINGH, B.; SHARMA, A . CFD analysis of greenhouse heating using flue gas and hot water heat sink pipe networks. Computers and Electronics in Agriculture, v.163, n.1. 2019. DOI: https:// doi.org/10.1016/j.compag.2019.104853.

DOTTO, M.; CASSOL, D.A.; JÚNIOR, A.W.; CITADIN, I. Indolbutyric acid on rooting of cuttings of mini rose bush. Ornamental Horticulture, v.22, n.1, p.43-49, 2016. DOI: https://doi.org/10.14295/ oh.v22i1.606.

ESPINAL-MONTES, V.; LORENZO LÓPEZ-CRUZ, I.; ROJANO-AGUILAR,A.; ROMANTCHIK KRIUCHOVA, E.; RAMÍREZ-ARIAS, A. Determination of night-time thermal gradients in a greenhouse using computational thermal dynamics. Agrociencia, v. 49, p.223-247. 2015.

ESPINOZA, K.; LÓPEZ, A.; VALERA, D.L.; MOLINAAIZ, F.D.; TORRES, J.A.; PEÑA, A. Effects of ventilator configuration on the flow pattern of a naturally-ventilated three-span Mediterranean greenhouse. Biosystems Engineering, v.164, n.1, p.13-30. 2017. DOI: https://doi. org/10.1016/j.biosystemseng.2017.10.001 
FIDAROS, D.K.; BAXEVANOU, C.A.; BARTZANAS, T.; KITTAS, C. Numerical simulation of thermal behavior of a ventilated arc greenhouse during a solar day. Renewble Energy, v.35, n.7, p.1380-1386. 2010. DOI: https://doi. org/10.1016/j.renene.2009.11.013.

FUENTES, M.K. A simplified thermal model for flat-plate photovoltaic arrays. Sandia National Labs. Albuquerque, NM (USA). 1987. Available at: <https://prod-ng.sandia. gov/techlib-noauth/access-control.cgi/1985/850330.pdf> Accessed June 02, 2019.

GOURDO, L.; FATNASSI, H.; BOUHARROUD, R.; EZZAERI, K., BAZGAOU, A.; WIFAYA, A.; DEMRATI, H.; BEKKAOUI, A.; AHAROUNE, A.; PONCET, C.; BOUIRDEN, L. Heating canarian greenhouse with a passive solar water-sleeve system: Effect on microclimate and tomato crop yield. Solar Energy, v.188, n.1, p.1349-1359. 2019. DOI: https://doi.org/10.1016/j.solener.2019.07.004

HE, K.S.; CHEN, D.Y.; SUN, L.J.; LIU, Z.L.; HUANG, Z.Y. The effect of vent openings on the microclimate inside multi-span greenhouses during summer and winter seasons. Engineering Applications of Computational Fluid Mechanics, v.9, n.1, p.399-410, 2015. DOI: https:// doi.org/10.1080/19942060.2015.1061553

KIM, R.; HONG, W.; LEE, S.; KWON, K.-S. Evaluation of wind pressure acting on multi-span greenhouses using CFD technique, Part 2: Application of the CFD model. Biosystems Engineering, v.164, n.1, p.257-280. 2017. DOI: https://doi.org/10.1016/j.biosystemseng.2017.09.011.

MAJDOUBI, H.; BOULARD, T.; FATNASSI, H.; SENHAJI, A., ELBAHI, S., DEMRATI, H., MOUQALLID, M., BOUIRDEN, L. Canary Greenhouse CFD Nocturnal Climate Simulation. Open Journal of Fluid Dynamics, v6, n.1, p.88-100. 2016. DOI: https://doi.org/10.4236/ ojfd.2016.62008

MAJDOUBI, H., FATNASSI, H., BOULARD, T., SENHAJI, A., DEMRATI, H., MOUQALLID, M., BOUIRDEN, L. Computational study of thermal performance of an unheated canarian-Type greenhouse: Influence of the opening configurations on airflow and climate patterns at the crop level, in: Acta Horticulturae, v.1182, n.1, p.87-94. 2017. DOI: https://doi.org/10.17660/ ActaHortic.2017.1182.10

MCCARTNEY, L.; ORSAT, V.; LEFSRUD, M.G An experimental study of the cooling performance and airflow patterns in a model Natural Ventilation Augmented Cooling (NVAC) greenhouse. Biosystems Engineering, v.174, n.1, p.173-189. 2018. DOI: https://doi.org/10.1016/j. biosystemseng.2018.07.005
MESMOUDI, K.M.; BOURNET, P.E. Thermal analysis of greenhouses installed under semi arid climate. International Journal of Heat and Technology. v.35, n.3. p.474-486. 2017. DOI: https://doi.org/10.18280/ ijht.350304

MINISTERIO DE AGRICULTURA Y DESARROLLO RURAL (MADR). Estadísticas del sector 2017- sector Cadena flores. Available at: $<$ https://www.minagricultura. gov.co/Paginas / default.aspx>. Accessed May 03, 2019.

MONTERO, J.I.; MUÑOZ, P.; ANTÓN, A.; IGLESIAS, N. COMPUTATIONAL FLUID DYNAMIC MODELLING OF NIGHT-TIME ENERGY FLUXES IN UNHEATED GREENHOUSES. Acta Horticulturae, v. 691, n.1, p.403-410. 2005. DOI: https://doi.org/10.17660/ ActaHortic.2005.691.48

MONTERO, J.I.; MUNOZ, P.; BAEZA, E.; STANGHELLINI, C. Ongoing developments in greenhouse climate control, in: V International Symposium on Models for Plant Growth, Environment Control and Farming Management in Protected Cultivation 1182. pp. 1-14. 2016

MONTERO, J.I.; MUÑOZ, P.; SÁNCHEZ-GUERRERO, M.C.; MEDRANO, E.; PISCIA, D., LORENZO, P. Shading screens for the improvement of the night time climate of unheated greenhouses. Spanish Journal of Agricultural Research, v.11, n.1, p.32-46. 2013. DOI: https://doi. org/10.5424/sjar/2013111-411-11.

PISCIA, D.; MONTERO, J.I.; BAEZA, E.; BAILEY, B.J. A CFD greenhouse night-time condensation model. Biosystems Engineering, v.111, n.2, p.141-154. 2012. DOI: https://doi.org/10.1016/j.biosystemseng.2011.11.006

PISCIA, D.; MUÑOZ, P.; PANADÈS, C., MONTERO, J.I. A method of coupling CFD and energy balance simulations to study humidity control in unheated greenhouses. Computers and Electronics in Agriculture, v. 115, n.1. p.129-141. 2015. DOI: https://doi.org/10.1016/j. compag.2015.05.005

REIS, M.V.; FIGUEIREDO, J.R.M.; PAIVA, R.; SILVA, D.P.C.; FARIA, C.V.N.; ROUHANA, L. Salinity in rose production. Ornamental Horticulture. v.22, n.2. 2016. DOI: https://doi.org/10.14295/oh.v22i2.904

REID, A. Greenhouse roses for cutflower production. Department of Agriculture and Food, Western Australia, Perth. Bulletin 4738. 2008. Available at: <https:// researchlibrary.agric.wa.gov.au/cgi/viewcontent.cgi?articl $\mathrm{e}=1168$ \& context $=$ bulletins $>$. Accessed June 01, 2019. 
SWINBANK, W.C. Long-wave radiation from clear skies. Quarterly Journal of the Royal Meteorological Society, v. 89, n.381, p.339-348. 1963.

VALERA, D.L.; MOLINA, F.D.; ÁLVAREZ, A.J.; LÓPEZ, J.A.; TERRÉS-NICOLI, J.M.; MADUEÑO, A. Contribution to characterisation of insect-proof screens: Experimental measurements in wind tunnel and CFD simulation, in: Acta Horticulturae, v.691, n.1, p.441-448. 2005. DOI: https://doi.org/10.17660/ ActaHortic.2005.691.53

VILLAGRAN, M.E.A.; BOJACA, A.C.R. Study of natural ventilation in a Gothic multi-tunnel greenhouse designed to produce rose (Rosa spp.) in the high-Andean tropic. Ornamental Horticulture, v.25, n.2, p.133-143. 2019a. DOI: https://doi.org/https://doi.org/10.14295/ oh.v25i2.2013
VILLAGRAN, M.E.A.; BOJACA, A.C.R. Effects of surrounding objects on the thermal performance of passively ventilated greenhouses. Journal of Agricultural Engineering, v.L856, n.1, p.20-27. 2019b. DOI: https:// doi.org/10.4081/jae.2019.856

VILLAGRAN, M.E.A.; BOJACA, A.C.R. Determination of the Thermal Behavior of a Colombian Hanging Greenhouse Applying CFD Simulation. Revista Ciencias Técnicas Agropecurias, v.28, n.3, p.1-10. 2019c.

VILLAGRAN, M.E.A.; BOJACA, A.C.R. BAHAMON, N.A.R. Determinacion del comportamiento térmico de un invernadero espacial colombiano mediante dinámica de fluidos computacional. Revista U.D.C.A Actualidad y Divulgacion Cientifica, v.21, n.2, p.415-426. 2018. DOI: https://doi.org/https://doi.org/10.31910/rudca.v21. n2.2018.10700 